Andrzej Zatęski ${ }^{1,2}$, Marcin Banasiuk $^{3}$, Katarzyna Karpierz $^{4}$, Ernest Kuchar ${ }^{4}$, Edyta Podsiadty $^{5,6}$

\title{
THE CLINICAL COURSE OF GASTROENTERITIS DUE TO NOSOCOMIALAND COMMUNITY-ACQUIRED NOROVIRUS INFECTIONS IN IMMUNOCOMPROMISED AND IMMUNOCOMPETENT CHILDREN - SINGLE CENTER EXPERIENCE
}

\author{
PRZEBIEG KLINICZNY SZPITALNYCH I POZASZPITALNYCH ZAKAŻEŃ \\ NOROWIRUSOWYCH U DZIECI ZDROWYCH I Z NIEDOBORAMI ODPORNOŚCI \\ - DOŚWIADCZENIE JEDNEGO OŚRODKA
}

\begin{abstract}
${ }^{1}$ Department of Infectious Diseases, Tropical Diseases and Hepatology, Medical University of Warsaw
${ }^{2}$ Hospital for Infectious Diseases, Warsaw, Poland

${ }^{3}$ Department of Paediatric Gastroenterology and Nutrition, Medical University of Warsaw

${ }^{4}$ Department of Paediatrics with Clinical Decision Unit, Medical University of Warsaw

${ }^{5}$ Department of Laboratory Diagnostics and Clinical Immunology of Developmental Age, Public Paediatric Teaching Hospital

${ }^{6}$ Institute of Medical Sciences, University of Rzeszów

${ }^{1}$ Klinika Chorób Zakaźnych, Chorób Tropikalnych i Hepatologii, Warszawski Uniwersytet Medyczny

${ }^{2}$ Wojewódzki Szpital Zakaźny w Warszawie, Polska

${ }^{3}$ Oddział Kliniczny Gastroenterologii, Żywienia Dzieci i Pediatrii, Warszawski Uniwersytet Medyczny

${ }^{4}$ Oddział Kliniczny Obserwacyjno-Izolacyjny i Pediatrii, Warszawski Uniwersytet Medyczny

${ }^{5}$ Zakład Diagnostyki Laboratoryjnej i Immunologii Klinicznej Wieku Rozwojowego, Dziecięcy Szpital Kliniczny

${ }^{6}$ Kolegium Nauk Medycznych, Uniwersytet Rzeszowski
\end{abstract}

\begin{abstract}
BACKGROUND. After the introduction of rotavirus vaccines into immunization schedules, noroviruses account for the majority of acute gastrointestinal infections. The aim of the study was to assess the clinical presentation in immunocompromised and immunocompetent children with hospital- and community-acquired norovirus gastroenteritis.

MATERIAL AND METHODS. We retrospectively reviewed clinical records of children with noroviral gastroenteritis, hospitalized in the Pediatric Hospital, Medical University of Warsaw, between 2015 and 2018. Acute gastrointestinal tract symptoms and confirmed etiology of noroviral infection were inclusion criteria. The analysis was performed in the subgroups of immunocompetent and immunocompromised patients, during community-acquired and nosocomial infections.

RESULTS. A total of 57 children with median age 1.5 year (IQR: 0.7-4.0) were recruited. The majority of patients were immunocompetent (87.7\%), and nosocomial infections were predominant (56.1\%). Gastrointestinal symptoms included nausea, vomiting and diarrhoea (in approximately $85 \%$ ), while systemic manifestations such as fever and malaise where observed in only $1 / 4$. Routine laboratory tests were normal in most of the patients. An analysis in the subgroups revealed statistically significant differences in blood $\mathrm{pH}$ and serum electrolyte levels - acidosis and electrolyte disturbances were statistically significantly more common in immunocompromised vs immunocompetent patients $(\mathrm{p}<0.05)$.

CONCLUSIONS. More frequently the clinical presentation includes gastrointestinal symptoms with no differences between immunocompromised and immunocompetent hosts. The median laboratory values were normal in generally healthy children; disturbances were observed only in children with immunodeficiencies. Therefore, prophylactic measures are of particular importance in the latter group, which is especially sensitive to severe and nosocomial infections.
\end{abstract}

Keywords: noroviruses, clinical outcomes, immunodeficiency, preventive measures 


\section{STRESZCZENIE}

WSTĘP. Po wprowadzeniu szczepionek przeciwko rotawirusom do programów szczepień ochronnych norowirusy zaczęły odpowiadać za większość ostrych infekcji żołądkowo-jelitowych. Celem badania była ocena obrazu klinicznego pozaszpitalnych i wewnątrzszpitalnych zakażeń przewodu pokarmowego wywołanych przez norowirusy u dzieci z prawidłową oraz obniżoną odpornością.

MATERIAŁ I METODY. Analizie retrospektywnej poddano dane kliniczne dzieci z ostrym nieżytem żołądka i jelit, hospitalizowanych w Szpitalu Pediatrycznym Warszawskiego Uniwersytetu Medycznego w latach 20152018. Kryteriami włączenia były ostre objawy ze strony przewodu pokarmowego i potwierdzona etiologia infekcji norowirusowej. Analizę przeprowadzono w podgrupach pacjentów z prawidłową i z obniżoną odpornością, w przebiegu zakażeń pozaszpitalnych i wewnątrzszpitalnych.

WYNIKI. Zrekrutowano ogółem 57 dzieci, średnia wieku wynosiła 1,5 roku (IQR: 0,7-4,0). Większość pacjentów była immunokompetentna $(87,7 \%)$, przeważały zakażenia szpitalne $(56,1 \%)$. Objawy żołądkowo-jelitowe obejmowały nudności, wymioty i biegunkę (u około 85\%), a objawy ogólnoustrojowe, takie jak gorączka i złe samopoczucie, obserwowano tylko u $1 / 4$ pacjentów. Podstawowe badania laboratoryjne były w zakresie wartości prawidłowych u większości pacjentów. Analiza w podgrupach wykazała istotne statystycznie różnice w: $\mathrm{pH}$ krwi oraz w poziomach elektrolitów w surowicy - kwasica i zaburzenia elektrolitowe były statystycznie istotnie częstsze u pacjentów z obniżoną odpornością niż u pacjentów z prawidłową odpornością $(\mathrm{p}<0,05)$.

WNIOSKI. Najczęściej obraz kliniczny zakażeń norowirusowych obejmuje objawy ze strony przewodu pokarmowego, bez różnic pomiędzy chorymi z prawidłową i obniżoną odpornością. Wyniki badań laboratoryjnych były w normie u ogólnie zdrowych dzieci; zaburzenia obserwowano tylko u dzieci z niedoborami odporności. $Z$ tego powodu środki zapobiegawcze mają szczególne znaczenie w drugiej grupie pacjentów, wyjątkowo wrażliwej na ciężki przebieg infekcji oraz częstsze zakażenia wewnątrzszpitalne.

Słowa kluczowe: norowirusy, przebieg kliniczny, zaburzenia odporności, środki zapobiegawcze

\section{INTRODUCTION}

Noroviruses (NoVs) are non-enveloped, singlestranded RNA viruses, which, together with Sapoviruses, belong to Caliciviridae family. NoVs are genetically diverse and are currently divided into 6 genogroups (I-VI), of which genogroups I [GI], II [GII] and IV [GIV] are known to infect humans. Based on the analysis of the major viral capsid protein (VP1), NoVs can be further classified into more than 31 different genotypes, with the NoV genogroup II, genotype 4 (GII.4) being the predominant genotype detected worldwide during the past decade $(1,2)$.

The incubation period is 12 to 48 hours. Viral excretion may start before the onset of symptoms; it peaks after several days and may persist for 3 weeks or more, especially in immunocompromised hosts. Although the infection may occur at any time of the year, it is more common during the colder months. Transmission is from person to person via fecal-oral and vomit-oral routes, contaminated water or food or dirty hands $(1,3,4)$. NoV is the most common cause of foodborne diseases as a result of infection acquired from infected food handlers. NoVs have also been detected in raw or unpasteurized milk and milk products (5). The virus is highly contagious and often causes large outbreaks with high attack rates in hospitals, schools, restaurants, etc $(1,3,4)$.

\section{WPROWADZENIE}

Norowirusy (NoV) to pozbawione otoczki jednoniciowe wirusy RNA, które wraz z Sapovirusami należą do rodziny Caliciviridae. NoV są genetycznie zróżnicowane i obecnie są podzielone na 6 grup genologicznych (I-VI), z których wiadomo, że genogrupy I [GI], II [GII] i IV [GIV] zakażają ludzi. Na podstawie analizy głównego wirusowego białka kapsydu (VP1), NoV można dalej klasyfikować do ponad 31 różnych genotypów, przy czym norowirusy genogrupy II, genotypu 4 (GII.4) są dominującym genotypem wykrywanym na całym świecie w ciągu ostatniej dekady $(1,2)$.

Okres inkubacji wynosi od 12 do 48 godzin. Wydalanie wirusa może rozpocząc się przed wystąpieniem objawów; osiąga maksimum po kilku dniach i może utrzymywać się przez 3 tygodnie lub dłużej, szczególnie u osób z obniżoną odpornością. Chociaż infekcja może wystąpić o każdej porze roku, częściej występuje w chłodniejszych miesiącach. Do zakażenia dochodzi drogą fekalno-oralną lub przez kontakt $\mathrm{z}$ wymiocinami, zanieczyszczoną wodą lub pokarmem $(1,3,4)$. NoV są uważane za najczęstszą przyczynę chorób przenoszonych przez pokarm, poprzez przeniesienie wirusa od zakażonych osób zajmujących się żywnością. NoV wykryto również w surowym lub niepasteryzowanym mleku i produktach mlecznych (5). Wirus jest wysoce zaraźliwy i często powoduje duże epidemie o wysokim wskaźniku zapadalności np. w szpitalach, szkołach, restauracjach itp. $(1,3,4)$. 
Typical symptoms of NoV infections include nausea, vomiting, abdominal pain and watery diarrhoea. The clinical course is similar to that of other types of viral gastroenteritis; therefore, making diagnosis on this basis is impossible. Acute diarrhoea without vomiting and a prolonged course of the disease are more common in children. In addition to gastrointestinal symptoms, systemic manifestations, such as fever and malaise, may also occur. Laboratory testing includes an enzyme immunoassay, rapid immunochromatographic assays and molecular diagnostic tests such as conventional RT-PCR, real-time RT-PCR or isothermal PCR for detection of viral antigens or RNA in stool samples $(1,6)$. The treatment involves adjuvant therapy: oral and intravenous hydration, restoration of electrolyte balance as well as the use of antipyretics and probiotics $(6,7,8)$. Currently, there is no available vaccine that protects against noroviruses.

\section{AIM}

The aim of the study was to characterize the clinical course of norovirus gastroenteritis in the subgroups of immunocompromised (IC-) and immunocompetent (IC+) paediatric patients with community-acquired and nosocomial infections.

\section{MATERIAL AND METHODS}

We retrospectively reviewed clinical data of patients diagnosed with acute norovirus gastroenteritis, hospitalized in the Paediatric Teaching Hospital, Medical University of Warsaw in Poland between October 2015 and June 2018 (a 3-year period).

Inclusion criteria were as follows: diagnosis of acute gastroenteritis (duration of symptoms less than 14 days), age between 0 and 18 years, and diagnosed norovirus infection based on fecal immunochromatography (Simple Norovirus, Operon, Spain) or real-time RT-PCR (Xpert Norovirus, Cepheid, Sweden). Both tests were used for genogroup I or II causative noroviruses. The sensitivity and specificity of immunochromatography were $85 \%$ and $96 \%$, respectively.

The exclusion criteria (other causes of acute gastroenteritis) were as follows:

- other viral infections (e.g. adeno/rotavirus),

- bacterial infections (e.g. Salmonella, Campylobacter, Yersinia),

- dietary mistake,

- onset of inflammatory diseases (e.g. cow milk allergy, IBD),

- onset of gastrointestinal functional diseases (e.g. cyclic vomiting, functional diarrhea).
Typowe objawy infekcji NoV obejmują nudności, wymioty, ból brzucha i wodnistą biegunkę. Przebieg kliniczny jest podobny do przebiegu innych rodzajów ostrego nieżytu żołądkowo-jelitowego, dlatego postawienie diagnozy na tej podstawie jest niemożliwe. Ostra biegunka bez wymiotów i przedłużony przebieg choroby występują częściej u dzieci. Oprócz objawów żołądkowo-jelitowych mogą również wystąpić objawy ogólnoustrojowe, takie jak gorączka i złe samopoczucie. Testy laboratoryjne obejmują: test immunoenzymatyczny, szybkie testy immunochromatograficzne i badania molekularne, takie jak konwencjonalna RT-PCR, RT-PCR w czasie rzeczywistym lub izotermiczna PCR do wykrywania antygenów wirusowych lub RNA w próbkach kału $(1,6)$. Leczenie obejmuje: nawodnienie doustne i dożylne, przywrócenie równowagi elektrolitowej, a także stosowanie leków przeciwgorączkowych i probiotyków $(6,7,8)$. Obecnie nie ma dostępnej szczepionki, która chroniłaby przed norowirusami.

\section{CEL}

Celem badania było scharakteryzowanie przebiegu klinicznego norowirusowego nieżytu żołądkowo-jelitowego w podgrupach pacjentów z obniżoną odpornością (IC-) i pacjentów z prawidłową odpornością (IC +) w przebiegu zakażeń pozaszpitalnych i wewnątrzszpitalnych.

\section{MATERIAŁ I METODY}

Ocenie retrospektywnej poddano dane kliniczne pacjentów ze zdiagnozowanym ostrym norowirusowym zapaleniem żołądka i jelit (ICD-10: A08.1), hospitalizowanych w Dziecięcym Szpitalu Klinicznym Warszawskiego Uniwersytetu Medycznego, w okresie od października 2015 r. do czerwca 2018 r. (okres 3 lat).

Kryteriami włączenia były: rozpoznanie ostrego zapalenia żołądka i jelit (czas trwania objawów poniżej 14 dni), wiek od 0 do 18 lat oraz zdiagnozowane zakażenie norowirusowe na podstawie testu z kału: immunochromatografii (Simple Norovirus, Operon, Hiszpania) lub RT-PCR w czasie rzeczywistym (Xpert Norovirus, Cefeid, Szwecja). Oba testy wykrywały norowirusy genogrupy I lub II. Czułość i swoistość immunochromatografii wynosiła odpowiednio 85\% i 96\%.

Kryteriami wykluczenia były:

- inne infekcje wirusowe (np. adeno/rotawirus),

- infekcje bakteryjne (np. Salmonella, Campylobacter, Yersinia),

- błąd dietetyczny,

- początek chorób zapalnych (np. alergia na białka mleka krowiego, nieswoiste zapalenia jelit),

- początek chorób czynnościowych przewodu pokarmowego (np. zespół wymiotów cyklicznych, biegunka czynnościowa). 
The data analyzed included age, sex, immunodeficiency and previous rotavirus vaccination, as well as the length of hospitalization for communityacquired NoV infections. We also reviewed the clinical course of disease: symptoms (fever, vomiting, diarrhea, abdominal pain) and laboratory findings: total blood count, peripheral blood biochemistry (C-reactive protein, electrolytes: $\mathrm{Na}+$ and $\mathrm{K}+$ ) and arterialized blood gases ( $\mathrm{pH}, \mathrm{HC} 03-)$.

The analysis was performed in the subgroups of immunocompetent and immunocompromised patients as well as patients with community-acquired and nosocomial infections.

Statistical methods. The distribution of continuous variables was analyzed by Shapiro-Wilk test. The data were expressed as median and interquartile range (IQR). Quantitative data were analyzed using U MannWhitney test and qualitative data were compared using the $\chi^{2}$ test or Fisher exact test. $\mathrm{P}$ value $<0.05$ was considered statistically significant.

\section{RESULTS}

Based on the inclusion and exclusion criteria, we recruited 57 children (male: female ratio $-1.6: 1$ ), with median age 1.5 years (IQR 0.7-4.0).

The majority of patients $(87.7 \%)$ were immunocompetent. A history of vaccination against rotaviruses was reported for $37.3 \%$ of patients.

In our cohort, nosocomial infections dominated (56.1\%) compared to community-acquired NoV infections $(43.9 \%)$. The average duration of hospitalization in patients with community-acquired infections was almost 6 days (median 4 days; IQR 3-8). The characteristics of the cohort is shown in Tables I and II.

The majority $(62.7 \%)$ of noroviral infections were detected by rapid immunochromatographic test, and the remaining $37.3 \%$ by RT-PCR. Laboratory diagnosis revealed that $98 \%$ of infections were caused by the genogroup II.

The infections occurred all year round. A total of 36 out of 57 cases were detected in winter (63\%), 26\% in spring, 1\% in summer, and 10\% in autumn.

Nausea $(86 \%)$, vomiting $(82.5 \%)$ and diarrhea (84.2\%) were the most common clinical manifestations. Abdominal pain was reported in $1 / 3(31.6 \%)$, while systemic manifestations including fever and malaise in only $1 / 4(22.8 \%)$ of the cohort (Table III).

An evaluation of laboratory findings revealed that total white blood cell count (WBC) ranged from 2.26 $\mathrm{x} 10^{3} / \mu \mathrm{L}$ to $28.47 \times 10^{3} / \mu \mathrm{L}$; with a median of $9.3 \mathrm{x}$ $10^{3} / \mu \mathrm{L}$ (IQR 5.8-15.3). C-reactive protein (CRP) was slightly elevated (norm up to $1 \mathrm{mg} / \mathrm{dL}$ ) and ranged from 0 to $8.3 \mathrm{mg} / \mathrm{dL}$; median $1.1 \mathrm{mg} / \mathrm{dL}$ (IQR 0.0-2.5).
Analizowane dane obejmowały: wiek, płeć, wywiad dotyczący niedoboru odporności i wcześniejsze szczepienia przeciw rotawirusom, a także długość hospitalizacji z powodu zakażeń NoV nabytych poza szpitalem. Przeanalizowaliśmy również przebieg kliniczny choroby: objawy (gorączka, wymioty, biegunka, ból brzucha) i wyniki badań laboratoryjnych: morfologię krwi obwodowej, badania biochemiczne (białko C-reaktywne, elektrolity: $\mathrm{Na}^{+} \mathrm{i} \mathrm{K}^{+}$) oraz gazometrię krwi arterializowanej $\left(\mathrm{pH}, \mathrm{HCO}_{3}^{-}\right)$.

Analizę przeprowadzono w podgrupach pacjentów z prawidłową odpornością i z obniżoną odpornością, a także z zakażeniami pozaszpitalnymi i wewnątrzszpitalnymi.

Metody statystyczne: rozkład zmiennych analizowano za pomocą testu Shapiro-Wilka. Dane wyrażono jako medianę i zakres międzykwartylowy (IQR). Dane ilościowe analizowano za pomocą testu U Manna -Whitneya, a dane jakościowe porównywano za pomocą testu $\chi^{2}$ lub testu Fishera. Wartość p $<0,05$ uznano za statystycznie istotna.

\section{WYNIKI}

W oparciu o kryteria włączenia i wyłączenia, zrekrutowano 57 dzieci (stosunek płci męskiej do żeńskiej - 1,6:1), z medianą wieku 1,5 roku (IQR 0,7-4,0).

Większość pacjentów $(87,7 \%)$ była immunokompetentna. Wcześniejsze szczepienie przeciwko rotawirusom wykonano u 37,3\% pacjentów.

W całej kohorcie dominowały zakażenia wewnątrzszpitalne $(56,1 \%)$ w porównaniu z zakażeniami NoV nabytymi poza szpitalem (43,9\%). Średni czas hospitalizacji u pacjentów z zakażeniami pozaszpitalnymi wynosił prawie 6 dni (mediana 4 dni; IQR 3-8). Charakterystykę kohorty pokazano w Tabelach I i II.

Większość (62,7\%) infekcji norowirusowych wykryto szybkim testem immunochromatograficznym, a pozostałe $37,3 \%$ metodą RT-PCR. 98\% zakażeń było spowodowanych przez genogrupę II.

Zakażenia występowały przez cały rok: 36 z 57 przypadków wykryto zimą (63\%), 26\% wiosną, 1\% latem i $10 \%$ jesienią.

Nudności (86\%), wymioty $(82,5 \%)$ i biegunka $(84,2 \%)$ były najczęstszymi objawami klinicznymi. Ból brzucha zgłosiła $1 / 3(31,6 \%)$, podczas gdy objawy ogólnoustrojowe, w tym gorączka i złe samopoczucie, występowały tylko 1/4 (22,8\%) pacjentów (Tab. III).

Ocena wyników badań laboratoryjnych wykazała, że całkowita liczba białych krwinek (WBC) wahała się od $2,26 \times 10^{3} / \mu \mathrm{L}$ do $28,47 \times 10^{3} / \mu \mathrm{L}$; z media-

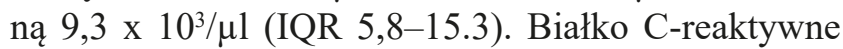
(CRP) było nieznacznie podwyższone (norma do 1 $\mathrm{mg} / \mathrm{dl}$ ) i wynosiło od 0 do $8,3 \mathrm{mg} / \mathrm{dl}$; mediana $1,1 \mathrm{mg} /$ dl (IQR 0,0-2,5). Analiza zaburzeń elektrolitowych 
An analysis of electrolyte disturbances showed that almost every child with norovirus gastroenteritis had normal electrolyte level $\left(\mathrm{Na}^{+}\right.$and $\mathrm{K}^{+}$within norm in $95.6 \%$ and $93.3 \%$, respectively). The maximum $\mathrm{Na}^{+}$ level was $172 \mathrm{mmol} / \mathrm{L}$ and the minimum $\mathrm{K}^{+}$level was $2.4 \mathrm{mmol} / \mathrm{L}$. wykazała, że prawie każde dziecko z norowirusowym zapaleniem żołądka i jelit miało prawidłowy poziom elektrolitów $\left(\mathrm{Na}^{+} \mathrm{i} \mathrm{K}^{+} \mathrm{w}\right.$ granicach normy odpowiednio u 95,6\% i 93,3\%). Maksymalny poziom $\mathrm{Na}^{+}$wynosił $172 \mathrm{mmol} / 1$, a minimalny poziom $\mathrm{K}^{+}$wynosił 2,4 $\mathrm{mmol} / \mathrm{l}$.

Table I. Characteristics of the cohort

Tabela I. Charakterystyka kohorty

\begin{tabular}{|c|c|c|c|c|c|}
\hline & All & $\mathrm{IC}+$ & IC - & $\begin{array}{l}\text { Nosocomial } \\
\text { NoV infection }\end{array}$ & $\begin{array}{l}\text { Community- } \\
\text { acquired NoV } \\
\text { infection }\end{array}$ \\
\hline & $\mathrm{n}=57$ & $\mathrm{n}=50(87.7 \%)$ & $\mathrm{n}=7(12 \%)$ & $\mathrm{n}=32(56.1 \%)$ & $n=25(43.9 \%)$ \\
\hline \multirow{2}{*}{ Age [years] (median, IQR) } & \multirow{2}{*}{$1.5(0.7-4.0)$} & $1.3(0.7-3.3)$ & $8(2.6-14.4)$ & $1(0.6-3.6)$ & $2.1(1.1-4)$ \\
\hline & & \multicolumn{2}{|c|}{$\mathrm{p}$-value $<0,05$} & \multicolumn{2}{|c|}{ p-value - n.s. } \\
\hline \multirow{2}{*}{ Sex: male $(n, \%)$} & \multirow{2}{*}{$35(61.4 \%)$} & $30(60 \%)$ & $5(71.4 \%)$ & $19(59.4 \%)$ & $19(64 \%)$ \\
\hline & & \multicolumn{4}{|c|}{ p-value - n.s. } \\
\hline \multirow{2}{*}{$\begin{array}{l}\text { Duration of symptoms before admission } \\
\text { [days](median, IQR) }\end{array}$} & \multirow{2}{*}{$1(0.5-2)$} & $1(0.5-2)$ & $2(1-3)$ & - & $1(0.5-2)$ \\
\hline & & \multicolumn{2}{|c|}{ p-value - n.s. } & & \\
\hline \multirow{2}{*}{ Duration of hospitalization [days] } & \multirow{2}{*}{$4(3-8)$} & $4(3-9)$ & $5.5(3-8)$ & - & $4(3-8)$ \\
\hline & & \multicolumn{2}{|c|}{ p-value - n.s. } & & \\
\hline \multirow{2}{*}{ Presence of rotavirus vaccine $(n, \%)$} & \multirow{2}{*}{$19(37.3 \%)$} & $19(42.2 \%)$ & $0(0 \%)$ & $8(29.6 \%)$ & $11(45.8 \%)$ \\
\hline & & & p-val & le - n.s. & \\
\hline \multirow{2}{*}{ Nosocomial infection } & \multirow{2}{*}{32} & 27 & 5 & \multirow{2}{*}{32} & \\
\hline & & p-value & - n.s. & & \\
\hline \multirow{2}{*}{$\begin{array}{l}\text { Duration of symptoms in patients with } \\
\text { nosocomial infection [days] (median, } \\
\text { IQR) }\end{array}$} & \multirow[b]{2}{*}{$4(3-5)$} & $4(3-5)$ & $5(3-8)$ & \multirow[b]{2}{*}{$4(3-5)$} & \\
\hline & & \multicolumn{2}{|c|}{ p-value - n.s. } & & \\
\hline \multirow{2}{*}{$\begin{array}{l}\text { Number of immunocompetent patients } \\
(\mathrm{n}, \%)\end{array}$} & & \multirow{2}{*}{$50(87.7 \%)$} & & $27(84.4 \%)$ & $23(92 \%)$ \\
\hline & & & & \multicolumn{2}{|c|}{ p-value - n.s. } \\
\hline
\end{tabular}

IC+ immunocompetent; IC- immunocompromised; n.s. - not significant

Table II. Characteristics of the cohort

Tabela II. Charakterystyka kohorty

\begin{tabular}{|c|c|c|c|c|}
\hline & All & $\mathrm{IC}+$ & IC- & p-value \\
\hline Community-acquired & $\mathrm{n}=25$ & $\mathrm{n}=23(92 \%)$ & $n=2(8 \%)$ & \\
\hline Age [years] (median, IQR) & $2.1(1.1-4)$ & $2.1(1.1-4)$ & $7.3(0.2-14.4)$ & \\
\hline Sex: male $(n, \%)$ & $19(64 \%)$ & $15(65.2 \%)$ & $1(50 \%)$ & n.s. \\
\hline Duration of symptoms before admission [days](median, IQR) & $1(0.5-2)$ & $1(0.5-2)$ & $2(1-3)$ & \\
\hline Duration of hospitalization [days](median, IQR) & $4(3-8)$ & $4(3-9)$ & $5.5(3-8)$ & \\
\hline Presence of rotavirus vaccine $(\mathrm{n}, \%)$ & $11(45.8 \%)$ & $11(50 \%)$ & $0(0 \%)$ & \\
\hline Nosocomial & $\mathrm{n}=32$ & $\mathrm{n}=27(84.4 \%)$ & $\mathrm{n}=5(15.6 \%)$ & \\
\hline Age (years) (median, IQR) & $1(0.6-3.6)$ & $0.8(0.5-2.9)$ & $8(2.8-11.8)$ & 0.009 \\
\hline Male (n, \%) & $19(59.4 \%)$ & $15(55.6 \%)$ & $4(80 \%)$ & \\
\hline $\begin{array}{l}\text { Duration of symptoms AT patients with nosocomial infection } \\
\text { [days](median, IQR) }\end{array}$ & $4(3-5)$ & $4(3-5)$ & $5(4-8)$ & n.s. \\
\hline Presence of rotavirus vaccine $(\mathrm{n}, \%)$ & $8(29.6 \%)$ & $8(34.8 \%)$ & $0(0 \%)$ & \\
\hline
\end{tabular}

IC+ immunocompetent; IC- immunocompromised; n.s. - not significant 
An analysis of blood gases, which was performed in more than half of the patients $(58 \%)$, revealed abnormalities in $41.2 \%$, including acidosis in 10 and alkalosis in 4 patients. The $\mathrm{pH}$ values ranged from 7.01 to 7.72 with median $\mathrm{pH}$ of 7.36. Normal $\mathrm{HCO}_{3}^{-}$levels were observed in $52.9 \%$ of patients $(\leq 21 \mathrm{mmol} / \mathrm{L}$ in $94 \%$ ), ranging from 7.3 to $36.1 \mathrm{mmol} / \mathrm{L}$, with the median level of $21.2 \mathrm{mmol} / \mathrm{L}$ (IQR 17.7-22.6).

Subgroup analysis. The following subgroups were distinguished: immunocompetent $(\mathrm{IC}+)$ and immunocompromised (IC-) patients, as well as community-acquired and nosocomial infections.

Norovirus gastroenteritis in immunocompetent and immunocompromised patients. Immunodeficiencies included leukaemias and AIDS. A statistically significant difference was observed in laboratory findings. Immunocompromised patients tended to have acidosis and electrolyte disturbances: elevated $\mathrm{Na}^{+}$and decreased $\mathrm{K}^{+}$were more frequent $(\mathrm{p}<0.05)$. The median duration of symptoms and hospitalization was longer among immunocompromised patients, although the difference was not statistically significant (Table I). Also, there was no statistically significant difference in the presence of symptoms between these two subgroups (Table III).
Analiza gazometrii wykonanej u ponad połowy pacjentów (58\%) wykazała nieprawidłowości u 41,2\%, w tym kwasicę u 10 i zasadowicę u 4 pacjentów. Wartości $\mathrm{pH}$ wahały się od 7,01 do 7,72 przy medianie $\mathrm{pH}$ wynoszącej 7,36. Prawidłowe poziomy $\mathrm{HCO}_{3^{-}}$obserwowano u 52,9\% pacjentów ( $\geq 21 \mathrm{mmol} / \mathrm{l}$ u $94 \%$ ); zakres od 7,3 do $36,1 \mathrm{mmol} / 1$, mediana $21,2 \mathrm{mmol} / \mathrm{l}$ (IQR 17,7-22,6).

Analiza w podgrupach. Wyróżniono następujące podgrupy: pacjentów z prawidłową odpornością (IC+) i z obniżoną odpornością (IC-), a także zakażenia pozaszpitalne i zakażenia wewnątrzszpitalne.

Norowirusowe zapalenie żolądka $\mathbf{i}$ jelit u pacjentów $\mathrm{z}$ prawidłową odpornością i z obniżoną odpornością. Niedobory odporności obejmowały białaczki i AIDS. Statystycznie istotną różnicę zaobserwowano w wynikach badań laboratoryjnych. U pacjentów z obniżoną odpornością kwasica metaboliczna i zaburzenia elektrolitowe: podwyższone $\mathrm{Na}^{+}$i obniżone $\mathrm{K}^{+}$występowały istotnie statystycznie częściej $(p<0,05)$. Mediana czasu trwania objawów i hospitalizacji była dłuższa wśród pacjentów z obniżoną odpornością, chociaż różnica nie była statystycznie istotna (Tab. I). Ponadto nie było statystycznie istotnej różnicy w rodzaju występujących objawów między tymi dwiema podgrupami (Tab. III).

Table III. The frequency of symptoms and laboratory tests results in the subgroups of immunocompetent and immunocompromised patients

Tabela III. Objawy kliniczne i wyniki badań laboratoryjnych w podgrupach pacjentów zdrowych i z zaburzeniami odporności

\begin{tabular}{|c|c|c|c|c|}
\hline & All & $\mathrm{IC}+$ & IC- & $\mathrm{p}$-value \\
\hline Laboratory tests & median (IQR) & median (IQR) & median (IQR) & \\
\hline WBC $(x 103 / \mu 1)$ & $9.3(5.8-15.3)$ & $9.5(7-16.1)$ & $5.4(3.5-14.4)$ & \\
\hline $\mathrm{CRP}(\mathrm{mg} / \mathrm{dl})$ & $1.1(0.0-2.5)$ & $0.7(0-2.5)$ & $1.7(1.1-4)$ & n.s. \\
\hline $\mathrm{HCO}_{3}^{-}(\mathrm{mmol} / \mathrm{l})$ & $21.2(17.7-22.6)$ & $21.7(17.8-22.9)$ & $17(12.2-19)$ & \\
\hline $\mathrm{pH}$ & $7.4(7.3-7.4)$ & $7.4(7.4-7.4)$ & $7.3(7.3-7.3)$ & 0.04 \\
\hline Electrolyte disturbances & n $(\%)$ & $\mathrm{n}(\%)$ & $\mathrm{n}(\%)$ & \\
\hline Elevated $\mathrm{Na}+$ & $2(4.4 \%)$ & $0(0 \%)$ & $2(33.3 \%)$ & 0.009 \\
\hline Decreased K+ & $3(6.7 \%)$ & $0(0 \%)$ & $3(50 \%)$ & 0.0002 \\
\hline Symptoms & n $(\%)$ & $\mathrm{n}(\%)$ & $\mathrm{n}(\%)$ & \\
\hline Fever & $13(22.8 \%)$ & $12(24 \%)$ & $1(14.3 \%)$ & \\
\hline Nausea & $49(86 \%)$ & $44(88 \%)$ & $5(71.4 \%)$ & \\
\hline Vomiting & $47(82.5 \%)$ & $43(86 \%)$ & $4(57.1 \%)$ & n.s. \\
\hline Diarrhoea & $48(84.2 \%)$ & $42(84 \%)$ & $6(85.7 \%)$ & \\
\hline Abdominal pain & $18(31.6 \%)$ & $14(28 \%)$ & $4(57.1 \%)$ & \\
\hline
\end{tabular}

IC+ immunocompetent; IC- immunocompromised; n.s. - not significant

Nosocomial and community-acquired norovirus gastroenteritis. There was no statistically significant difference in the characteristics of paediatric subgroups with nosocomial and community-acquired infections.
Wewnątrz- i pozaszpitalne norowirusowe zapalenie żołądka i jelit. Nie stwierdzono statystycznie istotnej różnicy $\mathrm{w}$ charakterystyce podgrup $\mathrm{z}$ zakażeniami szpitalnymi i zakażeniami pozaszpitalnymi. 
The symptoms and the laboratory findings were similar in both cohorts. For nosocomial infections, the average age of immunocompetent children was lower compared to immunocompromised children (p-value $<0.05$ ) (Table I). The clinical symptoms were similar in all patients. Evaluation of laboratory findings showed that most children had similar blood test results; however, a statistically significant difference was only seen in decreased $\mathrm{K}+$ serum levels $(\mathrm{p}<0.05)$ in immunocompromised hosts.

As for community-acquired infections, patients were admitted to hospital on the second day of symptoms. Average duration of hospitalization was estimated at 4 days (Table I). Laboratory findings revealed that immunocompromised patients with community-acquired infections tended to have abnormal blood gases $\left(\mathrm{pH}, \mathrm{HCO}_{3}^{-}\right)$compared to immunocompetent children $(\mathrm{p}<0.05)$. Figures 1 . and 2. show mean $\mathrm{HCO}_{3}^{-}$and $\mathrm{pH}$ in immunocompetent and immunocompromised patients with communityacquired infections.

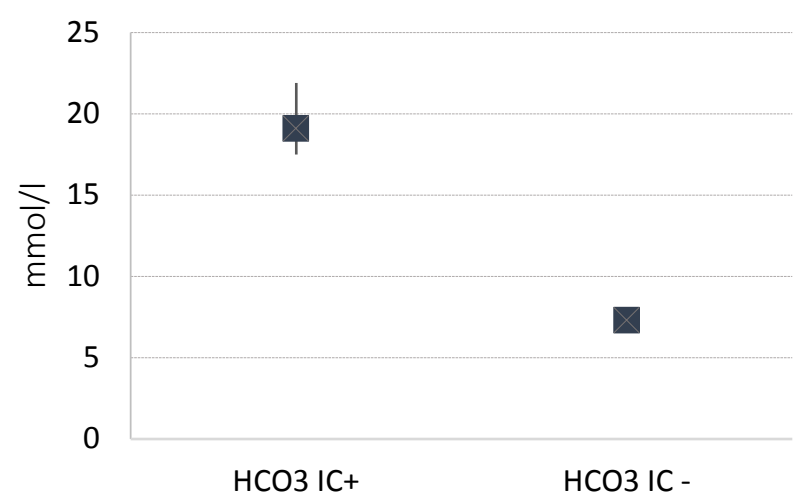

Fig. 1. $\mathrm{HCO}_{3}-$ levels $(\mathrm{mmol} / \mathrm{l})$ in immunocompetent and immunocompromised patients with communityacquired infections

Ryc. 1. Poziom $\mathrm{HCO}_{3}-(\mathrm{mmol} / \mathrm{l}) \mathrm{w}$ podgrupach pacjentów zdrowych i z zaburzeniami odporności w przebiegu infekcji pozaszpitalnych

\section{DISCUSSION}

In countries where rotavirus vaccines have been introduced to the universal vaccination programs, NoVs has become the main cause of sporadic infections and outbreaks of gastroenteritis $(3,4,9,10)$. Norovirus genogroup II (GII) was the predominant genotype detected worldwide during the past decade $(1,2)$. In the US alone, NoVs account for $60-70,000$ hospitalizations and nearly 1000 deaths annually, especially among young children and the elderly $(11,12)$. In Poland, where vaccinations against rotaviruses are recommended but not reimbursed, the level of immunization is moderate (about 25\%), rotaviruses are still the main etiological factor in acute
Objawy i wyniki laboratoryjne były podobne w obu kohortach. W przypadku zakażeń szpitalnych średni wiek dzieci z prawidłową odpornością był niższy w porównaniu z dziećmi z obniżoną odpornością $(\mathrm{p}<0,05)$ (Tab. I). Objawy kliniczne były podobne u wszystkich pacjentów. Ocena badań laboratoryjnych wykazała, że większość dzieci miała podobne wyniki, a statystycznie istotną różnicę zaobserwowano tylko w obniżonych poziomach $\mathrm{K}^{+} \mathrm{w}$ surowicy $(\mathrm{p}<0,05)$ u pacjentów $\mathrm{z}$ niedoborem odporności.

W przypadku zakażeń pozaszpitalnych, pacjentów przyjmowano najczęściej do szpitala drugiego dnia trwania objawów. Średni czas hospitalizacji oszacowano na 4 dni (Tab. I). Wyniki badań laboratoryjnych wykazały, że pacjenci z obniżoną odpornością z zakażeniami pozaszpitalnymi mieli nieprawidłowe wyniki gazometrii $\left(\mathrm{pH}, \mathrm{HCO}_{3}^{-}\right)$, w porównaniu $\mathrm{z}$ dziećmi z prawidłową odpornością $(\mathrm{p}<0,05)$. Ryciny 1 i 2 pokazują średnie wartości $\mathrm{HCO}_{3}^{-}$i $\mathrm{pH}$ u pacjentów z prawidłową i z obniżoną odpornością w przebiegu zakażeń pozaszpitalnych.

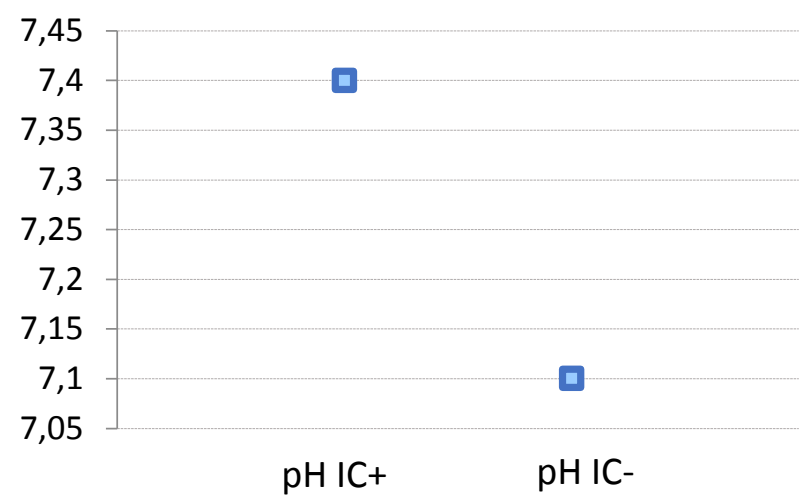

Fig. 2. pH levels in immunocompetent and immunocompromised patients with community-acquired infections

Ryc. 2. Poziom $\mathrm{pH}$ w podgrupach pacjentów zdrowych i z zaburzeniami odporności w przebiegu infekcji pozaszpitalnych

\section{DYSKUSJA}

W krajach, w których szczepionki przeciwko rotawirusom zostały wprowadzone do powszechnych programów szczepień, NoV stały się główną przyczyną zarówno sporadycznych infekcji jak i wybuchów epidemii zapalenia żołądka i jelit $(3,4,9,10)$. W ciągu ostatniej dekady genogroupa II (GII) jest dominująca i wykrywana na całym świecie $(1,2)$. W samych Stanach Zjednoczonych NoVs odpowiadają za 60-70 000 hospitalizacji i prawie 1000 zgonów rocznie, zwłaszcza wśród małych dzieci i osób starszych $(11,12)$. W Polsce, gdzie szczepienia przeciwko rotawirusom są zalecane, ale nie refundowane, poziom immunizacji jest umiarkowany (około 25\%), rotawirusy są nadal głównym czynni- 
gastroenteritis in all age groups, especially in children (13). Nevertheless, NoVs are the second definite most common viral cause of acute infectious diarrhea in Polish population and account for approximately 4000 laboratory confirmed cases (hospitalizations) of acute gastroenteritis each year (13). Almost all NoV infections identified in our study were caused by norovirus GII strains, which corresponds to the worldwide epidemiological pattern.

Noroviruses are highly contagious and often cause large outbreaks with high attack rates in hospitals, schools, restaurants, etc $(1,3,4)$. In a hospital setting, patients with NoVs infection can be the source of outbreaks, with a severe course especially among immunocompromised patients, such as cancer patients. In our study, most of infections (56\%) were acquired in hospital, with more than $10 \%$ of the affected children being immunocompromised.

Severe course of the disease with ion disturbances requiring prompt ion balance restoration was observed only among immunocompromised patients. Therefore, it is very important to emphasize that in addition to standard precautions, contact isolation is recommended for suspected cases of acute gastroenteritis caused by NoVs until 48 hours after symptom resolution. Appropriate hand hygiene with water and soap is probably the most important method to prevent NoV infection and control transmission. Soap is more effective than alcohol gels; cleaning surfaces with sodium hypochlorite (chlorine bleach) is recommended $(4,6,14)$. During the period analyzed, we observed no large outbreaks involving many cases, which confirms that the mentioned standard hospital hygiene procedures are sufficient to prevent the spread of norovirus in a closed population.

Despite the mild course of NoVs infections with predominant gastrointestinal symptoms without fever, biochemistry (including CRP) was performed in most patients, with no significant changes in hospital care or treatment used. Blood gas analysis was performed only in half of the patients and revealed abnormalities in half of them.

The weakness of our study is that we analyzed only symptomatic patients, so our description of norovirus infections does not include asymptomatic patients and patients with benign infections in whom hospitalization was not necessary and diagnostic tests were not performed.

\section{CONCLUSIONS}

Our study indicates that symptomatic norovirus infections are most common in young children and are mild but require a relatively long hospital stay. kiem etiologicznym ostrego zapalenia żołądka i jelit we wszystkich grupach wiekowych, szczególnie u dzieci (13). Niemniej jednak NoV są drugą najczęstszą wirusową przyczyną ostrej biegunki zakaźnej w polskiej populacji i odpowiadają za około 4000 potwierdzonych laboratoryjnie przypadków (hospitalizacji) ostrego zapalenia żołądka i jelit każdego roku (13). Prawie wszystkie infekcje NoVs zidentyfikowane w naszym badaniu były spowodowane szczepami norowirusa GII, co odpowiada ogólnoświatowemu wzorcowi epidemiologicznemu.

Norowirusy są wysoce zaraźliwe i często powodują duże epidemie o wysokim wskaźniku zapadalności np. w szpitalach, szkołach, restauracjach itp. $(1,3,4)$. W warunkach szpitalnych pacjenci z zakażeniem NoV mogą być źródłem ognisk, szczególnie wśród pacjentów z obniżoną odpornością, takich jak pacjenci z nowotworami. W naszym badaniu większość zakażeń (56\%) wystąpiła w szpitalu, a ponad $10 \%$ dotkniętych dzieci miało obniżoną odporność.

Ciężki przebieg choroby z zaburzeniami jonowymi wymagającymi szybkiego przywrócenia równowagi zaobserwowano tylko u pacjentów z obniżoną odpornością. Dlatego bardzo ważne jest podkreślenie, że oprócz standardowych środków ostrożności zaleca się izolację kontaktową już w przypadku podejrzenia ostrego zapalenia żołądka i jelit spowodowanego przez NoV, nawet do 48 godzin po ustąpieniu objawów. Właściwa higiena rąk za pomocą wody i mydła jest prawdopodobnie najważniejszą metodą zapobiegania infekcji NoV i kontroli transmisji. Mydło jest bardziej skuteczne niż żele alkoholowe; zalecane jest czyszczenie powierzchni podchlorynem sodu (wybielaczem chlorowym) $(4,6,14)$. W analizowanym okresie nie zaobserwowano dużych epidemii obejmujących wiele przypadków, co potwierdza, że wspomniane standardowe procedury higieny szpitalnej są wystarczające, aby zapobiec rozprzestrzenianiu się norowirusa w zamkniętej populacji.

Pomimo łagodnego przebiegu zakażeń NoVs z dominującymi objawami żołądkowo-jelitowymi bez gorączki, u większości pacjentów wykonano badania biochemiczne (w tym CRP), bez znaczącego wpływu na opiekę szpitalną lub na stosowane leczenie. Analizę gazometrii przeprowadzono tylko u połowy pacjentów, a u połowy z nich stwierdzono nieprawidłowości.

Słabością badania jest analiza przeprowadzona tylko wśród pacjentów objawowych - charakterystyka infekcji NoV nie obejmuje pacjentów bezobjawowych i pacjentów z łagodnym przebiegiem zakażenia, u których hospitalizacja nie była konieczna i nie przeprowadzono testów diagnostycznych.

\section{WNIOSKI}

Nasze badanie wskazuje, że objawowe zakażenia norowirusowe są najbardziej charakterystyczne dla 
In the vast majority the clinical presentation do not differ between immunocompromised and immunocompetent patients nor between nosocomial and community-acquired infections.

The analysis of blood gases and electrolyte levels revealed statistically significant differences in immunocompromised hosts. Therefore, we recommend that blood gas analysis, which is easy to perform and relatively inexpensive, should be performed in every dehydrated patient (not only due to noroviral infection) rather than biochemistry (such as CRP).

Immunocompromised patients, especially sensitive to severe and nosocomial infections, require exact application of preventive measures.

\section{REFERENCES}

1. Red Book, 30 $0^{\text {th }}$ Edition 2015 Report of the Committee on Infectious Diseases, Elk Grove Village 2015: 573-574.

2. Chen $\mathrm{H}, \mathrm{Hu} \mathrm{Y}$. Molecular diagnostics methods for detection and characterization of human Noroviruses. Open Microb J, 2016; 10: 79.

3. Chong W. Norovirus: a challenging pathogen. Healthcare Infection, 2013; 18: 133-142.

4. Bányai K, Estes MK, Martella V, et al. Viral gastroenteritis. Lancet, 2018; 392: 175-186.

5. American Academy of Pediatrics. Committee on Infectious Diseases and Committee on Nutrition. Consumption of Raw or Unpasteurized Milk and Milk Products by Pregnant Women and Children. Pediatrics, 2014; 133: 175-179.

6. Guarino A, Ashkenazi S, Gendrel D, et al. ESPGHAN/ESPID Evidence-Based Guidelines for the Management of Acute Gastroenteritis in Children in Europe: Update 2014. J Pediatr Gastroenterol Nutr, 2014; 1: 132-152.

7. Szajewska H, Guarino A, Hojsak I, et al. Use of Probiotics for Management of Acute Gastroenteritis: A Position Paper by the ESPGHAN Working Group for Probiotics and Prebiotics (2014). J Pediatr Gastroenterol Nutr, 2016; 62: 188.

8. Allen SJ, Martinez EG, Gregorio GV, et al. Probiotics for treating acute infectious diarrhea. Cochrane Review, 2010; 11. doi: 10.1002/14651858.CD003048.pub3.

9. Chong W. Norovirus: a challenging pathogen. Healthcare Infection, 2013; 18: 133-142.

10. Centers for Disease Control and Prevention. Surveillance for Foodborne Disease Outbreaks United States, 2009-2015. MMWR Morb Mortal Wkly Rep, 2018; 67: 1-11. małych dzieci, zazwyczaj przebiegają łagodnie, ale wymagają względnie długiego pobytu w szpitalu.

Najczęściej przebieg kliniczny nie różni się znacząco pomiędzy pacjentami ogólnie zdrowymi i z niedoborami odporności, zarówno w przebiegu zakażeń wewnątrz jak i pozaszpitalnych.

Analiza gazometrii i poziomów elektrolitów ujawniła statystycznie istotne różnice pomiędzy pacjentami ogólnie zdrowymi i z niedoborami odporności - dlatego też sugerujemy, aby to właśnie gazometrię, która jest łatwa do wykonania i stosunkowo niedroga, a nie badania biochemicznie (np. CRP), wykonywać u każdego odwodnionego pacjenta (nie tylko z powodu infekcji NoV).

Pacjenci immunoniekompetentni, bardziej wrażliwi na cięższe, nabyte w szpitalu zakażenia, szczególnie wymagają stosowania środków zapobiegawczych.

11. Payne DC, Vinjé J, Szilagyi PG, et al. Norovirus and medically attended gastroenteritis in U.S. children. N Eng J Med, 2013; 368: 1121-1130.

12. Centers for Disease Control and Prevention, Vital Signs: Foodborne Norovirus Outbreaks - United States, 2009-2012. MMWR Morb Mortal Wkly Rep, 2014; 63: 491-495.

13. Choroby Zakaźne i Zatrucia w Polsce w 2017 roku. Narodowy Instytut Zdrowia Publicznego Państwowy Zakład Higieny i Główny Inspektorat Sanitarny: Warszawa, 2018: 37-39. http://wwwold. pzh.gov.pl/oldpage/epimeld/2017/Ch_2017.pdf.

14. Centers for Disease Control and Prevention. Updated Norovirus Outbreak Management and Disease Prevention Guidelines. MMWR Morb Mortal Wkly Rep, 2011; 60: 1-15.

Received: 06.11.2019

Accepted for publication: 20.02.2020

Otrzymano: 06.11.2019 r.

Zaakceptowano do publikacji: 20.02.2020 r.

Adres do korespondencji:

Address for correspondence:

Dr n. med. Andrzej Załęski

Klinika Chorób Zakaźnych, Chorób Tropikalnych

i Hepatologii, Warszawski Uniwersytet Medyczny,

ul. Wolska 37, 01-201 Warszawa

telefon: 048600982185

e-mail: andrzejzaleski84@wp.pl 